\title{
Thromboses and Hemostasis Disorders Associated with COVID-19: The Possible Causal Role of Cross-Reactivity and Immunological Imprinting
}

\author{
Darja Kanduc ${ }^{1 \odot}$ \\ ${ }^{1}$ Department of Biosciences, Biotechnologies and Biopharmaceutics, \\ University of Bari, Bari, Italy
}

Glob Med Genet 2021;8:162-170.
Address for correspondence Darja Kanduc, PhD, Department of Biosciences, Biotechnologies, and Biopharmaceutics, University of Bari, Via Orabona 4, Bari 70125, Italy (e-mail: dkanduc@gmail.com).

Abstract
Keywords
- COVID-19
- SARS-CoV-2 spike gP
- cross-reactivity
- immunological
imprinting
- thromboses-related
proteins
- thromboses
- vascular diseases
- bleeding

By examining the issue of the thromboses and hemostasis disorders associated with severe acute respiratory syndrome-coronavirus-2 (SARS-CoV-2) through the lens of cross-reactivity, it was found that 60 pentapeptides are shared by SARS-CoV-2 spike glycoprotein (gp) and human proteins that- when altered, mutated, deficient or, however, improperly functioning - cause vascular diseases, thromboembolic complications, venous thrombosis, thrombocytopenia, coagulopathies, and bleeding, inter alia. The peptide commonality has a relevant immunological potential as almost all of the shared sequences are present in experimentally validated SARS-CoV-2 spike gpderived epitopes, thus supporting the possibility of cross-reactions between the viral gp and the thromboses-related human proteins. Moreover, many of the shared peptide sequences are also present in pathogens to which individuals have previously been exposed following natural infection or vaccinal routes, and of which the immune system has stored imprint. Such an immunological memory might rapidly trigger anamnestic secondary cross-reactive responses of extreme affinity and avidity, in this way explaining the thromboembolic adverse events that can associate with SARS-CoV2 infection or active immunization.

\section{Introduction}

Clinical studies have shown that severe acute respiratory syndrome-coronavirus-2 (SARS-CoV-2) infection can lead to an increased incidence of disorders such as thrombosis, venous thrombosis, and pulmonary embolism..$^{1-3} \mathrm{~A}$ main conclusion of these studies is that, although it cannot be proven that the hypercoagulable state is a direct causative effect of SARS-CoV-2 infection, nonetheless it is apparent that patients with SARS-CoV-2 could have a predilection to the occurrence of thromboembolic events. ${ }^{1}$

received

April 13, 2021

accepted after revision

April 26, 2021

published online

June 26, 2021
However, currently there are no hypotheses or data that might suggest a molecular mechanism that relates to such SARS-CoV-2-related thromboembolic events. Searching for possible mechanisms, the present study analyzes the SARSCoV-2 spike glycoprotein (gp) for peptide sharing, that is, molecular mimicry, with human proteins, alterations of which may cause thromboses and hemostasis diseases. The underlying scientific rationale is that peptides common to a pathogen and the human host may lead to autoimmune pathologies through cross-reactivity phenomena following pathogen infection. ${ }^{4-6}$ The results indicate that several linear

\section{(C) 2021. The Author(s).}

This is an open access article published by Thieme under the terms of the Creative Commons Attribution License, permitting unrestricted use, distribution, and reproduction so long as the original work is properly cited. (https://creativecommons.org/licenses/by/4.0/) Georg Thieme Verlag KG, Rüdigerstraße 14, 70469 Stuttgart, Germany 
sequences shared between the SARS-CoV-2 spike gp and human proteins related to thromboembolic events can possibly generate pathogenic autoantibodies via cross-reactivity and immunologic imprinting phenomena, in this way leading to thromboses and hemostasis disorders.

\section{Materials and Methods}

Peptide sharing between spike gp (NCBI, GenBank Protein Accession, ID: QHD43416.1) from SARS-CoV-2 and human proteins related to thromboses and hemostasis disorders was analyzed as previously detailed. ${ }^{4-6}$ In brief, pentapeptides were used as sequence probes since a peptide grouping formed by five amino acid (aa) residues defines a minimal immune determinant that can (1) induce highly specific antibodies, and (2) determine antigen-antibody specific interaction. ${ }^{7,8}$ Human proteins linked to thromboses and hemostasis disorders were retrieved from UniProtKB database (www.uniprot.org). ${ }^{9}$ Methodologically the spike gp primary sequence was dissected into pentapeptides offset by one residue (i.e., MFVFL, FVFLV, VFLVL, FLVLL, and so forth) and the resulting viral pentapeptides were analyzed for occurrences within the human proteins related to thromboses and hemostasis disorders. Then, the shared peptides were also controlled for occurrences in the pathogens Bordetella pertussis, Corynebacterium diphtheriae, Clostridium tetani, Haemophilus influenzae, and Neisseria meningitidis.

The immunological potential of the peptides shared between SARS-CoV-2 spike gp and thrombosis-related proteins was analyzed by searching the Immune Epitope DataBase (IEDB [www.iedb.org/] $)^{10}$ for immunoreactive SARS-CoV-2 spike gp-derived epitopes hosting the shared pentaptides.

\section{Results and Discussion}

\section{Peptide Sharing between SARS-CoV-2 Spike Glycoprotein and Thromboses-Related Human Proteins}

- Table 1 shows that 60 minimal immune determinants are shared between SARS-CoV-2 spike gp and 44 human proteins that-when altered, mutated, deficient or, however, improperly functioning-may cause diseases that include

Table 1 Pentapeptide sharing between SARS-CoV-2 spike gp and human proteins linked when altered, mutated, or deficient to blood diseases

\begin{tabular}{|c|c|c|}
\hline Shared peptides & Human proteins and associated functions/pathologies ${ }^{a, b}$ & References \\
\hline MTKTS, NLLLQ & $\begin{array}{l}\text { ADTRP (androgen-dependent TFPI-regulating protein) } \\
\text { Regulates the anticoagulant activity of the tissue factor pathway inhibitor, dys- } \\
\text { functions of which lead to vascular diseases }\end{array}$ & 11 \\
\hline TQLPP, PRTFL & $\begin{array}{l}\text { ALG12: Dol-P-Man: Man(7)GICNAC(2)-PP-Dol } \alpha \text {-1,6-mannosyltransferase } \\
\text { Psychomotor retardation, hypotonia, coagulation disorders, and immunodeficiency }\end{array}$ & 12 \\
\hline SAIGK & $\begin{array}{l}\text { ALG8: Dolichyl pyrophosphate GIc1Man9GIcNAc2 } \alpha \text {-1,3-glucosyltransferase } \\
\text { Pathologies: see ALG12 above }\end{array}$ & 13 \\
\hline AEIRA & $\begin{array}{l}\text { ANXA6 (annexin A6) } \\
\text { Anticoagulant protein from human placenta }\end{array}$ & 14 \\
\hline QLIRA, IRASA & $\begin{array}{l}\text { AP3B1 (AP-3 complex subunit } \beta-1) \\
\text { Associates with Hermansky-Pudlak syndrome. Bleeding diathesis resulting in } \\
\text { bruising, epistaxis, gingival bleeding, postpartum hemorrhage, bleeding }\end{array}$ & 15 \\
\hline LIGAE & $\begin{array}{l}\text { APLP2 (amyloid-like protein } 2 \text { ) } \\
\text { The soluble form may have inhibitory properties toward coagulation factors and } \\
\text { regulates cerebral thrombosis }\end{array}$ & 16 \\
\hline VLLPL & $\begin{array}{l}\text { B3AT (band } 3 \text { anion transport protein) } \\
\text { Involved in venous thrombosis of unknown origin }\end{array}$ & 17 \\
\hline FGGVS & $\begin{array}{l}\text { B4GT1 ( } \beta \text {-1,4-galactosyltransferase 1) } \\
\text { Defects in the nervous system development, psychomotor retardation, dysmorphic } \\
\text { features, hypotonia, coagulation disorders }\end{array}$ & 18 \\
\hline KGYHL & $\begin{array}{l}\text { C4BPB (C4b-binding protein } \beta \text { chain) } \\
\text { Controls complement activation; binds as a cofactor to } C 3 \mathrm{~b} / \mathrm{C} 4 \mathrm{~b} \text { inactivator; } \\
\text { possibly involved in the susceptibility to venous thrombosis }\end{array}$ & 19,20 \\
\hline LTVLP & $\begin{array}{l}\text { CBS (cystathionine } \beta \text {-synthase) } \\
\text { CBS-deficient patients are prone to vascular thrombosis }\end{array}$ & 21 \\
\hline NSVAY & $\begin{array}{l}\text { CO1A1 (collagen } \alpha-1(I) \text { chain) } \\
\text { Connective tissue disorders characterized by fragile, bruisable skin }\end{array}$ & 22,23 \\
\hline PGQTG, NGLTG & $\begin{array}{l}\text { CO1A2 (collagen } \alpha-2(I) \text { chain) } \\
\text { Pathology: see CO1A1 above }\end{array}$ & 22,23 \\
\hline TQSLL, GTGVL & $\begin{array}{l}\text { COG1 (conserved oligomeric Golgi's complex subunit 1) } \\
\text { Psychomotor retardation, hypotonia, coagulation disorders, and immunodeficiency }\end{array}$ & 24 \\
\hline
\end{tabular}

(Continued) 
Table 1 (Continued)

\begin{tabular}{|c|c|c|}
\hline Shared peptides & Human proteins and associated functions/pathologies ${ }^{\mathrm{a}, \mathrm{b}}$ & References \\
\hline STNLV, GAISS & $\begin{array}{l}\text { COG2. (conserved oligomeric Golgi's complex subunit 2) } \\
\text { Pathology: as for COG1 }\end{array}$ & 25 \\
\hline PINLV & $\begin{array}{l}\text { COG5 (conserved oligomeric Golgi's complex subunit 5) } \\
\text { Pathology: as for COG1 }\end{array}$ & 26 \\
\hline LPFQQ, PFQQF, IGKIQ & $\begin{array}{l}\text { ENTP1 (ectonucleoside triphosphate diphosphohydrolase 1) } \\
\text { Implicated in the prevention of platelet aggregation }\end{array}$ & 27,28 \\
\hline YTSAL & $\begin{array}{l}\text { EPHB2 (ephrin type-B receptor 2) } \\
\text { Regulation of platelet activation and blood coagulation }\end{array}$ & 29 \\
\hline VLNDI & $\begin{array}{l}\text { F13A (coagulation factor XIII A chain) } \\
\text { Relates to hematologic disorders characterized by bleeding tendency }\end{array}$ & 30 \\
\hline DPLQP & $\begin{array}{l}\text { FA5 (coagulation factor } V \text { ) } \\
\text { Central regulator of hemostasis. Parahemophilia, i.e., poor clotting; pregnancy loss, } \\
\text { ischemic stroke, thrombophilia }\end{array}$ & $31-34$ \\
\hline PPLLT, FVTQR & $\begin{array}{l}\text { FA8 (coagulation factor VIII) } \\
\text { Hemophilia }\end{array}$ & 35 \\
\hline NSYEC & $\begin{array}{l}\text { FA9 (coagulation factor IX) } \\
\text { Hemophilia }\end{array}$ & 35 \\
\hline SSANN & $\begin{array}{l}\text { FIBA (fibrinogen } \alpha \text { chain) } \\
\text { Bleeding, amyloidosis, arterial hypertension, hepatosplenomegaly, cholestasis, } \\
\text { petechial skin rash; thromboembolic complications }\end{array}$ & $36-38$ \\
\hline GAGAA & $\begin{array}{l}\text { GATA4 (transcription factor GATA-4) } \\
\text { Regulates factor } \mathrm{X} \text {, a vitamin K-dependent serine protease that functions in blood } \\
\text { coagulation. Can predispose to dilated cardiomyopathy, and to premature death }\end{array}$ & $39-41$ \\
\hline NDPFL & $\begin{array}{l}\text { GP1BA (platelet glycoprotein Ib } \alpha \text { chain) } \\
\text { Epistaxis; hemorrhage; menorrhagia; purpura; congenital bleeding diathesis; large } \\
\text { platelets; thrombocytopenia; long bleeding time }\end{array}$ & 42 \\
\hline ALLAG & $\begin{array}{l}\text { GPIX (platelet glycoprotein IX) } \\
\text { Epistaxis; hemorrhage; menorrhagia; purpura; congenital bleeding diathesis; large } \\
\text { platelets; thrombocytopenia; long bleeding time }\end{array}$ & 42 \\
\hline KLIAN & $\begin{array}{l}\text { HABP2 (hyaluronan-binding protein 2) } \\
\text { Serine protease involved in coagulation fibrinolysis and inflammatory pathways }\end{array}$ & 43 \\
\hline TQLPP & $\begin{array}{l}\text { HPS4 (Hermansky-Pudlak syndrome } 4 \text { protein) } \\
\text { Epistaxis; reduced visual acuity; horizontal nystagmus; iris transillumination; re- } \\
\text { strictive lung disease; bruising; bleeding tendency; menorrhagia; absence of } \\
\text { platelet dense bodies; lack of secondary aggregation response of platelets }\end{array}$ & 44 \\
\hline HTSPD & $\begin{array}{l}\text { HPS5 (Hermansky-Pudlak syndrome } 5 \text { protein) } \\
\text { As HPS4 above }\end{array}$ & 45 \\
\hline FNATR, DRLIT & $\begin{array}{l}\text { HS3S5 (heparan sulfate glucosamine 3-O-sulfotransferase 5) } \\
\text { Catalyzes a crucial step in the biosynthesis of the anticoagulant heparan sulfate }\end{array}$ & 46 \\
\hline SASFS & $\begin{array}{l}\text { ITA2 (integrin } \alpha-2 \text { ) } \\
\text { Associates with increased ischemic stroke risk; thrombophilia }\end{array}$ & 47,48 \\
\hline VRDLP & $\begin{array}{l}\text { ITB3 (integrin } \beta-3 \text { ) } \\
\text { Thrombasthenia, characterized by mucocutaneous bleeding }\end{array}$ & 49 \\
\hline FGTTL, YDPLQ, GDISG & $\begin{array}{l}\text { JAK2 (tyrosine-protein kinase JAK2) } \\
\text { Thrombophilia, thrombocytosis }\end{array}$ & 50,51 \\
\hline VNLTT, GDSSS, VTYVP & $\begin{array}{l}\text { MMRN1 (multimerin-1) } \\
\text { Deficiency in multimerin-1 associates with bleeding disorder }\end{array}$ & 52 \\
\hline LLPLV & $\begin{array}{l}\text { PLF4 (Platelet factor 4) } \\
\text { Involved in thrombosis }\end{array}$ & 53 \\
\hline TFGAG & PLMN (plasminogen) may be associated with susceptibility to thrombosis & 54 \\
\hline TVEKG, TGTGV & $\begin{array}{l}\text { PROS: vitamin K-dependent protein } S \\
\text { Anticoagulant plasma protein. Helps to prevent coagulation and stimulates fibri- } \\
\text { nolysis. Deficiency leads to impaired blood coagulation and a tendency to venous } \\
\text { thrombosis }\end{array}$ & 55,56 \\
\hline
\end{tabular}


Table 1 (Continued)

\begin{tabular}{|l|l|l|}
\hline Shared peptides & Human proteins and associated functions/pathologies ${ }^{\text {a,b }}$ & References \\
\hline LALHR & $\begin{array}{l}\text { PROZ: vitamin K-dependent protein Z } \\
\text { Helps hemostasis by binding thrombin and promoting its association with phos- } \\
\text { pholipid vesicles. Deficiency may be a risk factor for retinal vessel occlusion }\end{array}$ & 57 \\
\hline IDRLI & $\begin{array}{l}\text { PTPRJ: receptor-type tyrosine-protein phosphatase } \eta \\
\text { Lack of PTPRJ leads to a bleeding tendency and defective arterial thrombosis }\end{array}$ & 58 \\
\hline VFAQV & $\begin{array}{l}\text { TF (tissue factor): Initiates blood coagulation by forming a complex } \\
\text { with circulating factor VIl or VIla }\end{array}$ & 59 \\
\hline LFRKS & THRB: Prothrombin: Functions in blood homeostasis & 60 \\
\hline AGAAL, GAALQ & $\begin{array}{l}\text { TRBM (thrombomodulin) } \\
\text { Relates to thrombophilia, venous thrombosis, and thromboembolic disease. TRBM } \\
\text { administration is beneficial in sepsis-induced coagulopathy and in disseminated } \\
\text { intravascular coagulations }\end{array}$ & $61-63$ \\
\hline TLLAL & TSP1 (thrombospondin-1): Coronary artery disease & 52,64 \\
\hline TLLAL, SCGSC & TSP2 (thrombospondin-2): Coronary artery disease & 52,64 \\
\hline VSSQC, LQYGS & $\begin{array}{l}\text { VWF (von Willebrand factor) } \\
\text { Von Willebrand's disease is characterized by deficiency of circulating VWF that is } \\
\text { otherwise structurally and functionally normal. Clinical features: impaired platelet } \\
\text { aggregation, cardiovascular diseases, mucocutaneous bleeding, epistaxis, } \\
\text { menorrhagia }\end{array}$ & $52,65-67$ \\
\hline
\end{tabular}

Abbreviations: gp, glycoprotein; SARS-CoV-2, severe acute respiratory syndrome-coronavirus-2.

${ }^{a}$ Human proteins given by Uniprot accession and name in italics.

${ }^{b}$ Functions and/or pathologies: data and further references from Uniprot, PubMed, and OMIM databases

coagulation disorders, bruising, bleeding, hemorrhages, retinal vessel occlusion, cerebral thrombosis, venous thrombosis, ischemic stroke, and thrombophilia, inter alia.

\section{Immunological Potential of the Viral versus Human Peptide Sharing}

The data shown in - Table $\mathbf{1}$ are quantitatively impressive and become strikingly preeminent from a pathological perspective when analyzed for their immunological potential. Indeed, exploration of the $\operatorname{IEDB}^{10}$ reveals that nearly all the shared pentapeptides described in - Table $\mathbf{1}$ are also disseminated among SARS-CoV-2 spike gp-derived epitopes that have been experimentally validated as immunoreactive and are cataloged at the IEDB database (http://www.iedb.org). ${ }^{10}$

That is, - Table 2 concretely supports the possibility that autoimmune cross-reactions may be triggered by SARS-CoV2 infection/active immunization and hit human proteins related to thrombotic/thromboembolic disorders and coagulopathies, inter alia. Clinically, the vastity of the potential immunological cross-reactivity that emerges from - Table 2 indicates that mild-to-moderate and severe forms of thrombosis and coagulopathy may unavoidably accompany SARSCoV-2 infection/active immunization.

\section{Autoimmunity Potential and the Immunological Memory}

As already highlighted also in other infection models, ${ }^{68-71}$ one has to consider that immunologic memory can powerfully enhance and amplify the autoimmune crossreactivity potential because of interpathogen peptide sharing. Indeed, as a rule, the immune system recalls preexisting memory responses toward past infections rather than inducing ex novo responses toward the recent ones since hallmark of the immune system is the memory for the immune determinants it has previously encountered. ${ }^{72,73}$

Here, comparative sequence analyses show that 31 out of the 60 minimal immune determinants common to SARS-CoV-2 spike gp and human proteins related to thromboses are also widespread in pathogens, such as B. pertussis, C. diphtheriae, C. tetani, $H$. influenzae, and N. meningitidis, that are in pathogens with which, in general, an individual has already come into contact during his life due to infections or by vaccination ( - Table 3 ).

Hence, - Table 3 indicates the possibility that a preexisting immune response to previously encountered pathogens (in the present case: $B$. pertussis, $C$. tetani, C. diphtheriae, $H$. influenzae, and/or $N$. meningitidis) might be magnified and intensified following SARS-CoV-2 infection/active immunization. That is, immunological imprinting can start a chain of events according to which followings can be measured:

- Following exposure to SARS-CoV-2, the primary response to the virus can turn into a secondary response to previously encountered pathogens of which the immune system has stored an immunological memory.

- The anamnestic secondary and, by definition, extremely powerful response against immune determinants previously encountered implies not only that a low or no immune response will be evoked against the pathogen lastly encountered, that is, SARS-CoV-2, but also entails that the anamnestic secondary reaction against the early sensitizing pathogens-in the case in point, $B$. pertussis, $C$. tetani, C. diphtheriae, and/or N. meningitidis-will fail 
Table 2 Distribution of peptides shared between SARS-CoV-2 spike gp and human proteins related to thromboses and hemostasis disorders among 94 experimentally validated SARS-CoV-2 spike gp-derived epitopes

\begin{tabular}{|c|c|c|c|}
\hline$I^{a}$ & Epitope $^{b}$ & $I^{a}$ & Epitope $^{b}$ \\
\hline 1069137 & aqYTSALLAGtitsg & 1309555 & qcVNLTTrTQLPPaytnsft \\
\hline 1069290 & ctlksfTVEKGiyqt & 1309558 & qfnSAIGKIQdslsstasal \\
\hline 1071585 & nIVRDLPqgfsalep & 1309564 & qtragcLIGAEhvnNSYECd \\
\hline 1071723 & patvcgpkkSTNLVknkc & 1309573 & rLFRKSnlkpferdisteiy \\
\hline 1072807 & skhtPINLVRDLPqg & 1309595 & tnftisvtteilpvsMTKTS \\
\hline 1072965 & svtteilpvsMTKTS & 1309598 & tvYDPLQPeldsfkeeldky \\
\hline 1073281 & tesnkkfLPFQQFgrdia & 1309599 & Tyvpaqeknfttapaichdg \\
\hline 1073938 & vqIDRLITgrlqslq & 1309600 & tyvtqQLIRAAEIRASAnla \\
\hline 1074201 & ylyrLFRKSnlkpfe & 1309602 & vcgpkkSTNLVknkcvnfnf \\
\hline 1074838 & AEIRASAnlaatk & 1309603 & vknkcvnfnfNGLTGTGVLt \\
\hline 1074925 & hVTYVPaqeknf & 1309604 & VLNDIlsrldkveaevqidr \\
\hline 1074969 & IgaeNSVAYsnn & 1309621 & yskhtPINLVRDLPqgfsal \\
\hline 1074974 & ILALHRsyl & 1310254 & aeNSVAYsnnsiaip \\
\hline 1075005 & nqKLIANqf & 1310281 & aphgvvflhVTYVPa \\
\hline 1075031 & rLFRKSnlk & 1310303 & caqkfngLTVLPpll \\
\hline 1075039 & rqiaPGQTGkiadynykl & 1310336 & dskTQSLLivnnatn \\
\hline 1075066 & sVLNDIIsrl & 1310392 & FGTTLdskTQSLLiv \\
\hline 1075079 & tPINLVrdl & 1310401 & fkiyskhtPINLVrd \\
\hline 1075085 & tvYDPLQPeldsfk & 1310415 & fngLTVLPPLLTdem \\
\hline 1075094 & vlPPLLTdemiaqyt & 1310434 & GAISSVLNDIlsrld \\
\hline 1075125 & ysvlynSASFStfk & 1310444 & givnntvYDPLQPel \\
\hline 1075131 & yyvgylqPRTFLI & 1310487 & iginitrfqTLLALh \\
\hline 1087680 & PINLVRDLPqgfsalepl & 1310506 & irgwiFGTTLdsktq \\
\hline 1125063 & gLTVLPpll & 1310513 & itrfqTLLALHRsyl \\
\hline 1309117 & ggnynylyrLFRKSn & 1310592 & ILALHRsyltpgdss \\
\hline 1309118 & gpkkSTNLVknkcvn & 1310611 & IPPLLTdemiaqyts \\
\hline 1309123 & khtPINLVRDLPqgf & 1310633 & lyenqKLIANqfnsa \\
\hline 1309140 & tdemiaqYTSALLAG & 1310787 & SASFStfkcygvspt \\
\hline 1309147 & ylqPRTFLI & 1310828 & svlynSASFStfkcy \\
\hline 1309418 & AEIRASAnlaatkmsecvlg & 1310852 & tlvkqlssnfGAISS \\
\hline 1309442 & ayyvgylqPRTFLIkyneng & 1310865 & trfqTLLALHRsylt \\
\hline 1309450 & dplsetkctlksfTVEKGiy & 1310899 & VLLPLVSSQCVNLTT \\
\hline 1309451 & dsfkeeldkyfknHTSPDvd & 1310909 & VNLTTrTQLPPaytn \\
\hline 1309461 & ehvnNSYECdipigagicas & 1310927 & vtqnvlyenqKLIAN \\
\hline 1309464 & esnkkfLPFQQFgrdiadtt & 1310947 & wTFGAGAALQipfam \\
\hline 1309469 & fknHTSPDvdIGDISGinas & 1310979 & yvgylqPRTFLIkyn \\
\hline 1309470 & fknidgyfkiyskhtPINLV & 1311657 & ccSCGSCckfdeddsepvlkgvkl \\
\hline 1309475 & gccSCGSCckfdeddsepvl & 1311813 & rLFRKSnlkp \\
\hline 1309492 & ilditpcsFGGVSvitpgtn & 1313244 & nSASFStfk \\
\hline 1309506 & kvggnynylyrLFRKSnlkp & 1313285 & PINLVRDLPqgfsal \\
\hline 1309515 & IhrsyltpGDSSSgwtagaa & 1313286 & PINLVRDLPqgfwal \\
\hline 1309516 & litgrlqslqtyvtqQLIRA & 1314023 & ynylyrLFRKSnlkp \\
\hline
\end{tabular}


Table 2 (Continued)

\begin{tabular}{|l|l|l|l|}
\hline ID $^{\mathbf{a}}$ & Epitope $^{\mathbf{b}}$ & ID $^{\mathbf{a}}$ & Epitope $^{\mathbf{b}}$ \\
\hline 1309523 & IssnfGAISSVLNDIlsrld & 1317916 & gylqPRTFLI $^{\text {IPPLLTdem }}$ \\
\hline 1309524 & lyenqKLIANqfnSAIGKIQ & 1321084 & vYDPLQPeldsf \\
\hline 1309531 & NGLTGTGVLtesnkkflpfq & 1327418 & yenqKLIANqf \\
\hline 1309532 & ngLTVLPPLLTdemiaqyts & 1327923 & ytmslgaeNSVAY \\
\hline 1309534 & nitrfqTLLALHRsyltpgd & 1328800 & \\
\hline
\end{tabular}

Abbreviations: gp, glycoprotein; SARS-CoV-2, severe acute respiratory syndrome-coronavirus-2.

a Epitopes listed as the Immune Epitope DataBase ID.

bShared peptides given in capital letters.

Table 3 Occurrence in microbial organisms of pentapeptides common to SARS-CoV-2 spike gp, SARS-CoV-2 spike gp-derived epitome, and human proteins related to thromboses, coagulopathies, and hemostasis disorders

\begin{tabular}{|l|l|}
\hline Organism & Shared peptides \\
\hline Bordetella pertussis & $\begin{array}{l}\text { AEIRA, AGAAL, ALLAG, GAALQ, GAGAA, LLPLV, PFQQF, QLIRA, SSANN, TGTGV, VLLPL, } \\
\text { YDPLQ }\end{array}$ \\
\hline Corynebacterium diphtheriae & AEIRA, AGAAL, ALLAG, DPLQP, GAALQ, GAGAA, GTGVL, LLPLV, TVEKG \\
\hline Clostridium tetani & AGAAL, LQYGS \\
\hline Haemophilus influenzae & $\begin{array}{l}\text { AEIRA, AGAAL, FGGVS, GAALQ, GAGAA, GTGVL, KLIAN, LALHR, LLPLV, LPFQQ, LTVLP, } \\
\text { NLLLQ, NSVAY, TLLAL, TQSLL, VLLPL, VLNDI, VNLTT, YTSAL }\end{array}$ \\
\hline Neisseria meningitidis & AEIRA, AGAAL, ALLAG, DRLIT, GAALQ, GAGAA, IDRLI, KLIAN, LALHR, LTVLP, PINLV, TLLAL, \\
& VLLPL, VLNDI \\
\hline
\end{tabular}

Abbreviations: gp, glycoprotein; SARS-CoV-2, severe acute respiratory syndrome-coronavirus-2.

because those early sensitizing pathogens are no more present in the organism.

- As a final result, the anamnestic, high affinity, high avidity, and extremely powerful secondary immune response triggered by the lastly encountered pathogen (SARSCoV-2) and addressed toward past infections may find an outlet by hitting available human targets, that is, in the case in object, the human proteins related to thromboses and hemostasis diseases (-Table 1).

\section{Conclusion}

The last decades witnessed the emerging of infectious diseases and, consequently, intensive application of immunization procedures. Concomitantly, concerns about possible adverse events have increased. A recent crucial example is the immunization campaign with the dengue vaccine that highlighted the risk of enhanced disease after vaccination. $^{74}$

Today, the clinical context associated with SARS-CoV-2 infection/active immunization is no different. Actually, understanding whether undesired collateral events, such as the thrombotic manifestations and bleeding disorders discussed in this study, may causally associate with the viral infection/active immunization is a fundamental step for fighting the current pandemic. In this context, the present study:

- Analyzed the hypothesis that infectious agents can induce cross-reactive autoantibodies capable of hitting and al- tering human proteins that regulate hemostasis and coagulation.

- Showed that numerous peptides endowed with an immunologic potential are common to SARS-CoV-2 spike gp and human proteins, when mutated, altered, deficient or improperly functioning, are associated with thromboses and hemostasis diseases (-Tables $\mathbf{1}$ and $\mathbf{2}$ ).

- Documented that the peptide commonality extends to pathogens that usually have been already encountered by an individual during his life ( - Table 3 ).

Scientifically, the data indicate that peptide sharingassociated cross-reactivity and, in conjunction, immunological imprint might help explain some of the thromboembolic events that rapidly, massively, and violently may arise following SARS-CoV-2 infection/active immunization.

Clinically, the present data warrant testing of patients' sera for autoantibodies against the peptide targets described in -Tables 1-2 and 3, and reiterate the suggestion advanced already in $2000^{75}$ that immunotherapies should take advantage of the principle of peptide uniqueness, that is, of peptides present in the antigen of interest and absent in the human proteome. ${ }^{71,76-81}$

Funding

None.

Conflict of Interest

None declared. 


\section{References}

$1 \mathrm{Ng} \mathrm{JJ}$, Choong AMTL. Thromboembolic events in patients with SARS-CoV-2. J Vasc Surg 2020;72(02):760-761

2 Cui S, Chen S, Li X, Liu S, Wang F. Prevalence of venous thromboembolism in patients with severe novel coronavirus pneumonia. J Thromb Haemost 2020;18(06):1421-1424

3 Klok FA, Kruip MJHA, van der Meer NJM, et al. Incidence of thrombotic complications in critically ill ICU patients with COVID-19. Thromb Res 2020;191:145-147

4 Lucchese G, Capone G, Kanduc D. Peptide sharing between influenza A H1N1 hemagglutinin and human axon guidance proteins. Schizophr Bull 2014;40(02):362-375

5 Lucchese G, Kanduc D. Potential crossreactivity of human immune responses against HCMV glycoprotein B. Curr Drug Discov Technol 2016;13(01):16-24

6 Lucchese G, Kanduc D. Zika virus and autoimmunity: From microcephaly to Guillain-Barré syndrome, and beyond. Autoimmun Rev 2016;15(08):801-808

7 Kanduc D. Pentapeptides as minimal functional units in cell biology and immunology. Curr Protein Pept Sci 2013;14(02): 111-120

8 Kanduc D. Homology, similarity, and identity in peptide epitope immunodefinition. J Pept Sci 2012;18(08):487-494

9 UniProt Consortium. UniProt: a worldwide hub of protein knowledge. Nucleic Acids Res 2019;47(D1):D506-D515

10 Vita R, Mahajan S, Overton JA, et al. The Immune Epitope Database (IEDB): 2018 update. Nucleic Acids Res 2019;47(D1):D339-D343

11 Lupu C, Zhu H, Popescu NI, Wren JD, Lupu F. Novel protein ADTRP regulates TFPI expression and function in human endothelial cells in normal conditions and in response to androgen. Blood 2011; 118(16):4463-4471

12 Thiel C, Schwarz M, Peng J, et al. A new type of congenital disorders of glycosylation (CDG-Ii) provides new insights into the early steps of dolichol-linked oligosaccharide biosynthesis. J Biol Chem 2003;278(25):22498-22505

13 Schollen E, Frank CG, Keldermans L, et al. Clinical and molecular features of three patients with congenital disorders of glycosylation type Ih (CDG-Ih) (ALG8 deficiency). J Med Genet 2004;41 (07):550-556

14 Yoshizaki H, Mizoguchi T, Arai K, Shiratsuchi M, Shidara Y, Maki M. Structure and properties of calphobindin II, an anticoagulant protein from human placenta. J Biochem 1990;107(01):43-50

15 Huizing M, Malicdan MCV, Wang JA, et al. Hermansky-Pudlak syndrome: mutation update. Hum Mutat 2020;41(03):543-580

16 Xu F, Previti ML, Nieman MT, Davis J, Schmaier AH, Van Nostrand WE. AbetaPP/APLP2 family of Kunitz serine proteinase inhibitors regulate cerebral thrombosis. J Neurosci 2009;29(17):5666-5670

17 Chang WA, Sheu CC, Liu KT, Shen JH, Yen MC, Kuo PL. Identification of mutations in SLC4A1, GP1BA and HFE in a family with venous thrombosis of unknown cause by next-generation sequencing. Exp Ther Med 2018;16(05):4172-4180

18 Hansske B, Thiel C, Lübke T, et al. Deficiency of UDP-galactose:Nacetylglucosamine beta-1,4-galactosyltransferase I causes the congenital disorder of glycosylation type IId. J Clin Invest 2002; 109(06):725-733

19 Blom AM, Villoutreix BO, Dahlbäck B. Functions of human complement inhibitor C4b-binding protein in relation to its structure. Arch Immunol Ther Exp (Warsz) 2004;52(02):83-95

20 Buil A, Trégouët DA, Souto JC, et al. C4BPB/C4BPA is a new susceptibility locus for venous thrombosis with unknown protein S-independent mechanism: results from genome-wide association and gene expression analyses followed by case-control studies. Blood 2010;115(23):4644-4650

21 Sikora M, Lewandowska I, Marczak Ł, Bretes E, Jakubowski H. Cystathionine $\beta$-synthase deficiency: different changes in proteomes of thrombosis-resistant $\mathrm{Cbs}^{-/-}$mice and thrombosisprone $\mathrm{CBS}^{-/-}$humans. Sci Rep 2020;10(01):10726
22 Nuytinck L, Freund M, Lagae L, Pierard GE, Hermanns-Le T, De Paepe A. Classical Ehlers-Danlos syndrome caused by a mutation in type I collagen. Am J Hum Genet 2000;66(04):1398-1402

23 Malfait F, Symoens S, De Backer J, et al. Three arginine to cysteine substitutions in the pro-alpha (I)-collagen chain cause EhlersDanlos syndrome with a propensity to arterial rupture in early adulthood. Hum Mutat 2007;28(04):387-395

24 Foulquier F, Vasile E, Schollen E, et al. Conserved oligomeric Golgi complex subunit 1 deficiency reveals a previously uncharacterized congenital disorder of glycosylation type II. Proc Natl Acad Sci U S A 2006;103(10):3764-3769

25 Kodera H, Ando N, Yuasa I, et al. Mutations in COG2 encoding a subunit of the conserved oligomeric golgi complex cause a congenital disorder of glycosylation. Clin Genet 2015;87(05): 455-460

26 Paesold-Burda P, Maag C, Troxler H, et al. Deficiency in COG5 causes a moderate form of congenital disorders of glycosylation. Hum Mol Genet 2009;18(22):4350-4356

27 Kaczmarek E, Koziak K, Sévigny J, et al. Identification and characterization of CD39/vascular ATP diphosphohydrolase. J Biol Chem 1996;271(51):33116-33122

28 Savio LEB, Robson SC, Longhi MS. Ectonucleotidase modulation of lymphocyte function in gut and liver. Front Cell Dev Biol 2021; 8:621760

29 Berrou E, Soukaseum C, Favier R, et al. A mutation of the human EPHB2 gene leads to a major platelet functional defect. Blood 2018;132(19):2067-2077

30 Ivaskevicius $\mathrm{V}$, Biswas $\mathrm{A}$, Bevans $\mathrm{C}$, et al. Identification of eight novel coagulation factor XIII subunit A mutations: implied consequences for structure and function. Haematologica 2010;95 (06):956-962

31 Castoldi E, Simioni P, Kalafatis M, et al. Combinations of 4 mutations (FV R506Q, FV H1299R, FV Y1702C, PT 20210G/A) affecting the prothrombinase complex in a thrombophilic family. Blood 2000;96(04):1443-1448

32 Poursadegh Zonouzi A, Chaparzadeh N, Ghorbian S, et al. The association between thrombophilic gene mutations and recurrent pregnancy loss. J Assist Reprod Genet 2013;30(10): 1353-1359

33 Casas JP, Hingorani AD, Bautista LE, Sharma P. Meta-analysis of genetic studies in ischemic stroke: thirty-two genes involving approximately 18,000 cases and 58,000 controls. Arch Neurol 2004;61(11):1652-1661

34 Mumford AD, McVey JH, Morse CV, et al. Factor V I359T: a novel mutation associated with thrombosis and resistance to activated protein C. Br J Haematol 2003;123(03):496-501

35 Al-Allaf FA, Taher MM, Abduljaleel Z, et al. Molecular analysis of factor VIII and factor IX genes in hemophilia patients: identification of novel mutations and molecular dynamics studies. J Clin Med Res 2017;9(04):317-331

36 Asselta R, Platè M, Robusto $\mathrm{M}$, et al. Clinical and molecular characterisation of 21 patients affected by quantitative fibrinogen deficiency. Thromb Haemost 2015;113(03):567-576

37 Benson MD, Liepnieks J, Uemichi T, Wheeler G, Correa R. Hereditary renal amyloidosis associated with a mutant fibrinogen alphachain. Nat Genet 1993;3(03):252-255

38 Koopman J, Haverkate F, Grimbergen J, et al. Molecular basis for fibrinogen Dusart (A alpha 554 Arg->Cys) and its association with abnormal fibrin polymerization and thrombophilia. J Clin Invest 1993;91(04):1637-1643

39 Wilberding JA, Castellino FJ. Characterization of the murine coagulation factor X promoter. Thromb Haemost 2000;84(06): 1031-1038

40 Hung HL, Pollak ES, Kudaravalli RD, Arruda V, Chu K, High KA. Regulation of human coagulation factor $\mathrm{X}$ gene expression by GATA-4 and the Sp family of transcription factors. Blood 2001;97 (04):946-951 
41 Li RG, Li L, Qiu XB, et al. GATA4 loss-of-function mutation underlies familial dilated cardiomyopathy. Biochem Biophys Res Commun 2013;439(04):591-596

42 Almomani MH, Mangla A. Bernard soulier syndrome. In: StatPearls. Treasure Island, FL: StatPearls Publishing; 2021

43 Cheng YC, Stanne TM, Giese AK, et al; WTCCC-2 Consortium. Genome-wide association analysis of young-onset stroke identifies a locus on chromosome 10q25 near HABP2. Stroke 2016;47 (02):307-316

44 Anderson PD, Huizing M, Claassen DA, White J, Gahl WA. Hermansky-Pudlak syndrome type 4 (HPS-4): clinical and molecular characteristics. Hum Genet 2003;113(01):10-17

45 Botero JP, Chen D, Majerus JA, et al. Hermansky-Pudlak syndrome subtype 5 (HPS-5) novel mutation in a 65 year-old with oculocutaneous hypopigmentation and mild bleeding diathesis: the importance of recognizing a subtle phenotype. Platelets 2018;29 (01):91-94

46 Xia G, Chen J, Tiwari V, et al. Heparan sulfate 3-O-sulfotransferase isoform 5 generates both an antithrombin-binding site and an entry receptor for herpes simplex virus, type 1. J Biol Chem 2002; 277(40):37912-37919

47 Liu H, Wang Y, Zheng J, et al. Platelet glycoprotein gene Ia C807T, HPA-3, and Ib $\alpha$ VNTR polymorphisms are associated with increased ischemic stroke risk: Evidence from a comprehensive meta-analysis. Int J Stroke 2017;12(01):46-70

48 Reznik EV, Shcherbakova ES, Borisovskaya SV, et al. ST-elevation myocardial infarction, pulmonary embolism, and cerebral ischemic stroke in a patient with critically low levels of natural anticoagulants. J Cardiol Cases 2019;21(03):106-109

49 French DL, Coller BS. Hematologically important mutations: Glanzmann thrombasthenia. Blood Cells Mol Dis 1997;23(01): 39-51

50 Chung RT, Iafrate AJ, Amrein PC, Sahani DV, Misdraji J. Case records of the Massachusetts General Hospital. Case 15-2006. A 46-year-old woman with sudden onset of abdominal distention. N Engl J Med 2006;354(20):2166-2175

51 Stockklausner C, Duffert CM, Cario H, Knöfler R, Streif W, Kulozik AETHROMKID-Plus Studiengruppe der Gesellschaft für Thrombose- und Hämostaseforschung (GTH) and of Gesellschaft für Pädiatrische Onkologie und Hämatologie (GPOH). Thrombocytosis in children and adolescents-classification, diagnostic approach, and clinical management. Ann Hematol 2021;100(07): 1647-1665

52 Hayward CP, Rivard GE, Kane WH, et al. An autosomal dominant, qualitative platelet disorder associated with multimerin deficiency, abnormalities in platelet factor $\mathrm{V}$, thrombospondin, von Willebrand factor, and fibrinogen and an epinephrine aggregation defect. Blood 1996;87(12):4967-4978

53 Althaus K, Möller P, Uzun G, et al. Antibody-mediated procoagulant platelets in SARS-CoV-2-vaccination associated immune thrombotic thrombocytopenia. Haematologica 2021;106(08): 2170-2179

54 Ichinose A, Espling ES, Takamatsu J, et al. Two types of abnormal genes for plasminogen in families with a predisposition for thrombosis. Proc Natl Acad Sci U S A 1991;88(01):115-119

55 Boinot C, Borgel D, Kitzis A, Guicheteau M, Aiach M, Alhenc-Gelas M. Familial thrombophilia is an oligogenetic disease: involvement of the prothrombin G20210A, PROC and PROS gene mutations. Blood Coagul Fibrinolysis 2003;14(02):191-196

56 Makris M, Leach M, Beauchamp NJ, et al. Genetic analysis, phenotypic diagnosis, and risk of venous thrombosis in families with inherited deficiencies of protein S. Blood 2000;95(06): 1935-1941

57 Koren-Michowitz M, Eting E, Rahimi-Levene N, Garach-Jehoshua $\mathrm{O}$, Volcheck Y, Kornberg A. Protein Z levels and central retinal vein or artery occlusion. Eur J Haematol 2005;75(05):401-405
58 Senis YA, Tomlinson MG, Ellison S, et al. The tyrosine phosphatase CD148 is an essential positive regulator of platelet activation and thrombosis. Blood 2009;113(20):4942-4954

59 Bogdanov VY, Balasubramanian V, Hathcock J, Vele O, Lieb M, Nemerson Y. Alternatively spliced human tissue factor: a circulating, soluble, thrombogenic protein. Nat Med 2003;9(04): 458-462

60 Glenn KC, Frost GH, Bergmann JS, Carney DH. Synthetic peptides bind to high-affinity thrombin receptors and modulate thrombin mitogenesis. Pept Res 1988;1(02):65-73

61 Ohlin AK, Norlund L, Marlar RA. Thrombomodulin gene variations and thromboembolic disease. Thromb Haemost 1997;78(01): 396-400

62 Vincent JL, Francois B, Zabolotskikh I, et al; SCARLET Trial Group. Effect of a recombinant human soluble thrombomodulin on mortality in patients with sepsis-associated coagulopathy: The SCARLET randomized clinical trial. JAMA 2019;321(20): 1993-2002

63 Vincent JL, Ramesh MK, Ernest D, et al. A randomized, doubleblind, placebo-controlled, Phase $2 \mathrm{~b}$ study to evaluate the safety and efficacy of recombinant human soluble thrombomodulin, ART-123, in patients with sepsis and suspected disseminated intravascular coagulation. Crit Care Med 2013;41(09):2069-2079

64 Zhang XJ, Wei CY, Li WB, et al. Association between single nucleotide polymorphisms in thrombospondins genes and coronary artery disease: A meta-analysis. Thromb Res 2015;136(01): 45-51

65 Allen S, Abuzenadah AM, Hinks J, et al. A novel von Willebrand disease-causing mutation (Arg273Trp) in the von Willebrand factor propeptide that results in defective multimerization and secretion. Blood 2000;96(02):560-568

66 Horiuchi H, Doman T, Kokame K, Saiki Y, Matsumoto M. Acquired von Willebrand syndrome associated with cardiovascular diseases. J Atheroscler Thromb 2019;26(04):303-314

67 Mital A. Acquired von Willebrand syndrome. Adv Clin Exp Med 2016;25(06):1337-1344

68 Lucchese G, Kanduc D. The Guillain-Barrè peptide signatures: from Zika virus to campylobacter, and beyond. Virus Adaptation and Treatment 2017;9:1-11

69 Lucchese G, Kanduc D. Minimal immune determinants connect Zika virus, human Cytomegalovirus, and Toxoplasma gondii to microcephaly-related human proteins. Am J Reprod Immunol 2017;77(02):e12608

70 Kanduc D, Shoenfeld Y. Inter-pathogen peptide sharing and the original antigenic sin: solving a paradox. Open Immunol J 2018; 8:16-27

71 Kanduc D. Anti-SARS-CoV-2 immune response and sudden death: titin as a link. Adv Stud Biol 2021;13:37-44

72 Francis T, Salk JE, Quilligan JJ. Experience with vaccination against influenza in the spring of 1947: a preliminary report. Am J Public Health Nations Health 1947;37(08):1013-1016

73 Davenport FM, Hennessy AV, Francis T Jr. Epidemiologic and immunologic significance of age distribution of antibody to antigenic variants of influenza virus. J Exp Med 1953;98(06): 641-656

74 Halstead SB. Which dengue vaccine approach is the most promising, and should we be concerned about enhanced disease after vaccination? There is only one true winner. Cold Spring Harb Perspect Biol 2018;10(06):a030700. Doi: 10.1101/cshperspect. a030700

75 Natale C, Giannini T, Lucchese A, Kanduc D. Computer-assisted analysis of molecular mimicry between human papillomavirus 16 E7 oncoprotein and human protein sequences. Immunol Cell Biol 2000;78(06):580-585

76 Kanduc D. Peptide cross-reactivity: the original sin of vaccines. Front Biosci (Schol Ed) 2012;4:1393-1401 
77 Kanduc D. Immunogenicity, immunopathogenicity, and immunotolerance in one graph. Anticancer Agents Med Chem 2015;15 (10):1264-1268

78 Kanduc D. From anti-SARS-CoV-2 immune responses to COVID-19 via molecular mimicry. Antibodies (Basel) 2020; $9(03): 33$
79 Kanduc D. Immunobiology: on the inexistence of a negative selection process. Adv Stud Biol 2020;12:19-28

80 Kanduc D. Hydrophobicity and the physico-chemical basis of immunotolerance. Pathobiology 2020;87(04):268-276

81 Kanduc D. The role of proteomics in defining autoimmunity. Expert Rev Proteomics 2021;18(03):177-184 